University of Nebraska - Lincoln

DigitalCommons@University of Nebraska - Lincoln

1995

Reflectance in the Red and Near Infra-Red Ranges of the Spectrum as Tool for Remote Chlorophyll Estimation in Inland Waters: Lake Kinneret Case Study

Anatoly A. Gitelson

University of Nebraska - Lincoln, agitelson2@unl.edu

Yosef Z. Yacobi

Israel Oceanographic and Limnological Research Ltd., Kinneret Limnological Laboratory

Follow this and additional works at: https://digitalcommons.unl.edu/natrespapers

Part of the Natural Resources and Conservation Commons

Gitelson, Anatoly A. and Yacobi, Yosef Z., "Reflectance in the Red and Near Infra-Red Ranges of the Spectrum as Tool for Remote Chlorophyll Estimation in Inland Waters: Lake Kinneret Case Study" (1995). Papers in Natural Resources. 237.

https://digitalcommons.unl.edu/natrespapers/237

This Article is brought to you for free and open access by the Natural Resources, School of at DigitalCommons@University of Nebraska - Lincoln. It has been accepted for inclusion in Papers in Natural Resources by an authorized administrator of DigitalCommons@University of Nebraska - Lincoln. 


\title{
REFLECTANCE IN THE RED AND NEAR INFRA-RED RANGES OF THE SPECTRUM AS TOOL FOR REMOTE CHLOROPHYLL ESTIMATION IN INLAND WATERS - LAKE KINNERET CASE STUDY
}

\author{
Anatoly A. Gitelson ${ }^{1}$ and Yosef Z. Yacobi ${ }^{2}$

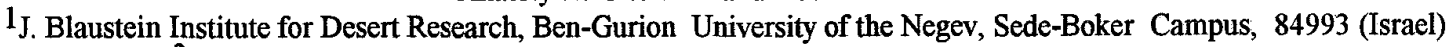 \\ 2 Israel Oceanographic and Limnological Research Ltd., Kinneret Limnological Laboratory
}

\begin{abstract}
Signature analysis of reflectance spectra was used for the selection of the most suitable spectral bands for remote sensing of chlorophyll in inland waters. The parameters of the reflectance peak near $700 \mathrm{~nm}$ were employed for construction of algorithms for chlorophyll determination. The best model, validated by independent data sets, enabled estimation of chlorophyll concentration with an error $<0.6 \mathrm{mg} / \mathrm{m}^{3}$ for period of low $\mathrm{Chl}$ concentration and $<6.5 \mathrm{mg} / \mathrm{m}^{3}$ for period of the phytoplankton bloom. For the purpose of chlorophyll mapping in Lake Kinneret, the use of three relatively narrow spectral bands was sufficient. Radiometric data were also used to simulate radiances in the channels of TM Landsat and to find algorithm for chlorophyll assessment. The ratio (TM2-TM3)/TM1 was used to retrieve chlorophyll in the range 3-10 $\mathrm{mg} / \mathrm{m}^{3}$ with an error of $<1 \mathrm{mg} \cdot \mathrm{m}^{-3}$; the ratio TM4/TM3 was used to map chlorophyll in the range $10-200 \mathrm{mg} / \mathrm{m}^{3}$ with 10 gradations.
\end{abstract}

\section{INTRODUCTION}

Water quality estimation by remotely sensed optical variables is based on wavelengths specific absorption and scattering of soluble and suspended matter in the aquatic medium. Of all the constituents chlorophyll (Chl) is the most important parameter for water quality characterization, being a probe of algal density. The estimation of $\mathrm{Chl}$ in marine oligotrophic waters has been successfully achieved by devising models which use the reflectance in the blue and green ranges of the visible light [1]. However in inland and productive coastal waters these models are hard to implement since several water constituents have noticeable impact on the light reflected by water in these spectral ranges, and they do not covary with $\mathrm{Chl}$ concentrations. In this paper novel models for $\mathrm{Chl}$ estimation based on the reflectance in the red and near infra-red ranges of the spectrum, developed for the subtropical Lake Kinneret, are presented.

\section{METHODS}

Two experiments were carried out in a period when the phytoplankton density was relatively low, however, the background concentration of non-organic suspended matter (SM) was high and variable. Two experiments were executed during Peridinium bloom, when $\mathrm{Chl}$ ranged from 3 to $187.5 \mathrm{mg} / \mathrm{m}^{3}$. Therefore, the four experiments covered the typical situation of suspendoids concentrations in the lake.

At each sampling station, the upwelling radiance of the water, $\mathrm{L}_{\mathrm{w}}$, and the upwelling radiance of a standard reflectance $\mathrm{BaSO}_{4}$ plate $\left(\mathrm{L}_{\mathrm{o}}\right)$ were measured with a portable LICOR LI-1800 radiometer in the range from 400 to $850 \mathrm{~nm}$. The measurements of upwelling radiance of the water have been done from the ship at the distance app. $2 \mathrm{~m}$ above the water surface using a telescope with a field of view of $15^{\circ}$. Each observed radiance spectrum of the water was divided by the appropriate spectrum of upwelling radiance of the reference plate to give a radiance reflectance as $\mathrm{R}=\mathrm{L}_{\mathrm{w}} / \mathrm{L}_{\mathrm{o}}$.

For determination of vertical attenuation coefficient, downwelling irradiance in the range from 400 to $750 \mathrm{~nm}$ was measured using remote cosine receptor just above $\left(E_{d n o}\right)$ and under the water surface at the depth of $80 \mathrm{~cm}\left(E_{\mathrm{dnz}}\right)$. Vertical attenuation coefficient was determined as $K_{d}=\log \left(E_{d n o} / E_{d n z}\right) / z$. For determination of reflectance under the water, downwelling $\left(\mathrm{E}_{\mathrm{dno}}\right)$ and upwelling $\left(\mathrm{E}_{\text {upo }}\right)$ irradiances were measured just under the water surface in the range 400 to $750 \mathrm{~nm}$. Underwater reflectance was determined as $\mathrm{R}_{\mathrm{o}}=\mathrm{E}_{\mathrm{upo}} / \mathrm{E}_{\mathrm{dno}}$.

For each experiment TM Landsat images were acquired. The TM images had to undergo a geometrical and atmospheric corrections [2].

\section{RESULTS AND DISCUSSION}

The temporal and spatial variation found in Lake Kinneret was very high in all the variables we measured in our experiments (Table 1). In the winterspring time the lake phytoplankton was dominated by 
the large dinoflagellate Peridinium gatunense, which forms high crop stands. In the summer-fall period green algae, diatoms and small dinoflagellates were the most of the phytoplankton. This basic difference of phytoplankton composition was clearly displayed in the nature of the reflectance and diffuse attenuation spectra collected above and under the water surface by high spectral resolution radiometer.

Table 1: Timing, sampling intensity and water quality parameters of Lake Kinneret (Dry weight and turbidity data were kindly provided by A. Parparov)

\begin{tabular}{|lllll|}
\hline & $\begin{array}{l}\text { October } \\
1992\end{array}$ & $\begin{array}{l}\text { March } \\
1993\end{array}$ & $\begin{array}{l}\text { April } \\
1993\end{array}$ & $\begin{array}{c}\text { July } \\
1994\end{array}$ \\
\hline No. samples & 20 & 40 & 37 & 39 \\
Chlorophyll $\left(\mathrm{mg} / \mathrm{m}^{3}\right)$ & $3.1-7.3$ & $5.1-185.0$ & $2.4-187.5$ & $5.3-26.0$ \\
Dry Weight $(\mathrm{mg} / \mathrm{l})$ & $1.8-4.8$ & $3.7-56.8$ & $1.5-54.7$ & $1.9-5.4$ \\
Secchi depth $(\mathrm{m})$ & $2.1-5.1$ & $0.4-3.9$ & $0.6-5.2$ & $1.5-4.6$ \\
Turbidity (NTU) & $1.2-4.2$ & $2.4-22.0$ & $1.9-21.0$ & $1.2-3.5$ \\
\hline
\end{tabular}

\section{Vertical attenuation coefficient spectra}

The spectra of vertical attenuation coefficient include several prominent features (Fig.1).

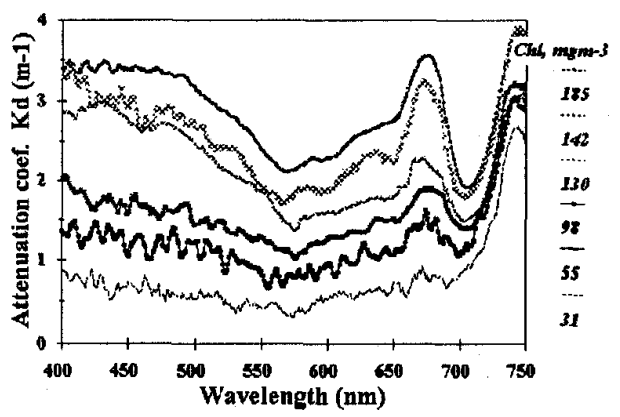

Fig. 1. Attenuation coefficient for downwelling irradiance. April 1994.

Decrease of attenuation coefficient was observed from 400 to $550 \mathrm{~nm}$. For samples with higher $\mathrm{Chl}$ concentration (more than $50 \mathrm{mg} / \mathrm{m}^{3}$ ), the reflectance increased reaching maximum at near $440 \mathrm{~nm}$. The peak at $440 \mathrm{~nm}$ corresponded to the blue Chl- $a$ absorption maximum. The attenuation coefficient decreased beyond $500 \mathrm{~nm}$, with a shoulder at $480-500 \mathrm{~nm}$. This absorption feature is due to carotenoids, which in the case of Peridinium are dominated by peridinin and diadinoxanthin [3]. The attenuation coefficient was lowest near $550 \mathrm{~nm}$, where absorption of all photosynthetic pigments reached minimum. A maximum at $675 \mathrm{~nm}$ corresponded to the red Chl-a absorption peak. Near $700 \mathrm{~nm}$, minimum of attenuation coefficient was recorded. The peak appeared at $700 \mathrm{~nm}$ for $\mathrm{Chl}<15 \mathrm{mg} / \mathrm{m}^{3}$ and reached $715 \mathrm{~nm}$ for $\mathrm{Chl}>150$ $\mathrm{mg} / \mathrm{m}^{3}$. Beyond $720 \mathrm{~nm}$ attenuation coefficient increased, achieving minimal values near $750 \mathrm{~nm}$.

\section{Reflectance spectra}

The acquired reflectance spectra were all similar in general outline (Fig. 2a). A sharp decrease around 440 $\mathrm{nm}$ corresponded to $\mathrm{Chl}$ absorption. A weak minimum at $520 \mathrm{~nm}$, due to absorption of carotenoids was also observed. The maximum, near $560-570 \mathrm{~nm}$ was caused by minimum absorption by all phytoplankton pigments. Near $600 \mathrm{~nm}$, the slope of spectral reflectance changed very sharply due to spectral behavior of the absorption coefficient of pure water.

In the red region of the spectrum, a weak minimum between 620 and $630 \mathrm{~nm}$ was sometimes observed. It corresponds to phycocyanin absorption of picocyanobacteria. From 670 to $675 \mathrm{~nm}$, minimum of reflectance was recorded. The minimum was evident for $\mathrm{Chl}>4 \mathrm{mg} / \mathrm{m}^{3}$, and hardly distinguished for $\mathrm{Chl}<$ $3.5 \mathrm{mg} / \mathrm{m}^{3}$. A small peak around $690 \mathrm{~nm}$, which varied from 685 to $695 \mathrm{~nm}$, was recorded in all spectra. This peak is a result of fluorescence emitted by phytoplankton [4]. Therefore, it is an important diagnostic feature of the reflectance spectrum, despite its modest size. At wavelengths beyond 690-695 nm the reflectance dropped sharply; the spectra converged to a common reflectance value at $750 \mathrm{~nm}$. 

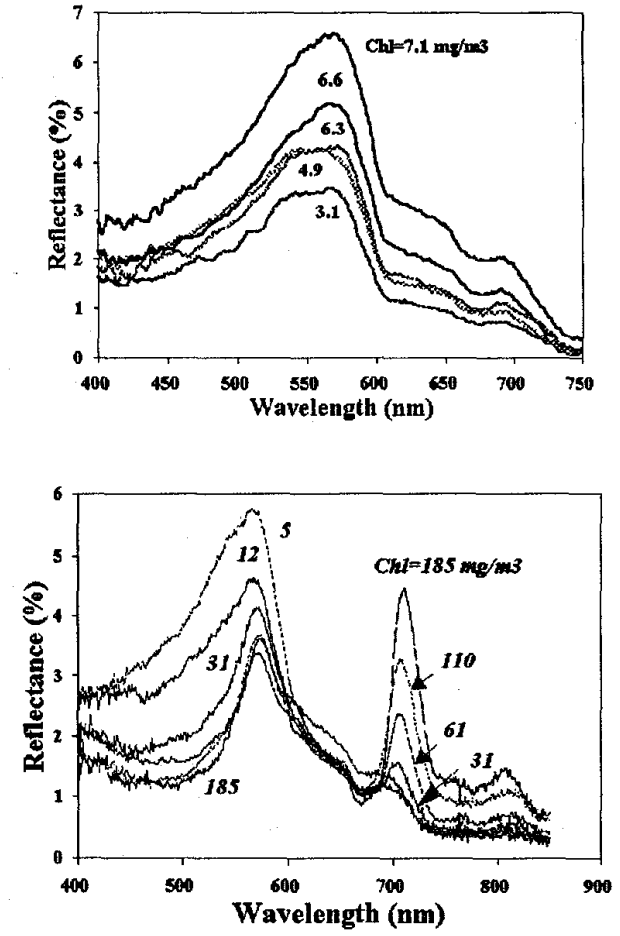

Fig. 2. Reflectance spectra obtained in October 1992 (a) and in March 1993 (b).

Representative reflectance spectra, acquired during Peridinium period are presented in Fig. $2 \mathrm{~b}$. For Chl concentrations higher than $20 \mathrm{mg} \cdot \mathrm{m}^{-3}$ a minimum is seen in the blue range of the spectrum. The reflectance peaked between 550 and $580 \mathrm{~nm}$. The peak width and its magnitude decreased with the increase of $\mathrm{Chl}$ concentration. In samples with the highest $\mathrm{Chl}$ concentration reflectance did not exceed $3 \%$ due to strong absorption by phytoplankton pigments. In the range from 590 to $650 \mathrm{~nm}$ the reflectance spectra of all the samples with $\mathrm{Chl}$ concentrations of more than $10 \mathrm{mg} / \mathrm{m}^{3}$ displayed minimal variation.

A reflectance minimum was found at $670 \mathrm{~nm}$. It was approximately $1 \%$ and was barely dependent on $\mathrm{Chl}$ concentration in a wide range from 10 to 187 $\mathrm{mg} / \mathrm{m}^{3}$. In samples with low $\mathrm{Chl}$ content, less than $5 \mathrm{mg} / \mathrm{m}^{3}$, a wide shoulder was found at $683 \mathrm{~nm}$, which corresponded to phytoplankton fluorescence. This peak was consistently found in Lake Kinneret during low $\mathrm{Chl}$ period (Fig. 2a). Red maximum showed near $700 \mathrm{~nm}$. The magnitude and position of this peak were strongly dependent on $\mathrm{Chl}$ content. The linear regression between the $\log (\mathrm{Chl})$ and the peak position could be summarized as follows (Fig. 3): Peak position $=677.1+15.5 * \log (\mathrm{Chl}), \mathrm{r}^{2}=0.9$, with an estimation error of peak position of 2.76 nm.

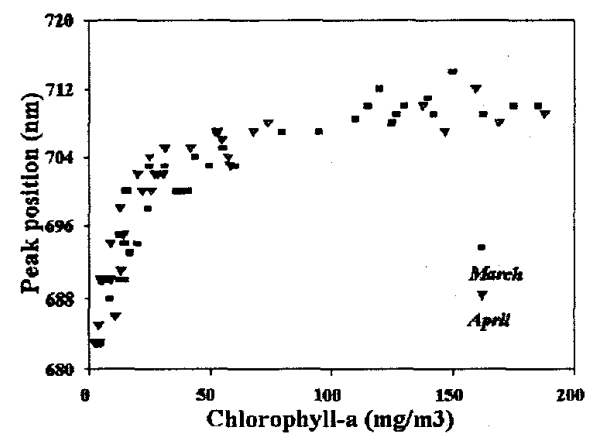

Fig. 3. Peak position versus chlorophyll concentration.

The blue absorption peak of chlorophyll- $a$, and carotenoids absorption are entirely masked by humus and tripton absorption (Fig. 1). The combined effects of dissolved organic matter, tripton and algae absorption at wavelengths shorter than $500 \mathrm{~nm}$, and the increased scattering toward shorter wavelengths makes the attempt to separate the contribution of each constituents to the reflectance in this spectral region a difficult task.

For high $\mathrm{Chl}$ concentrations in the region above $500 \mathrm{~nm}$, absorption slightly decreases, remaining, nevertheless, very high (Fig. 1). The reflectance in this region correspondingly remains low (Fig. 2b). The fact that absorption by peridinin, which in vivo peaks in the range from 490 to 510 , is the governing factor of reflectance in the green region, is caused by the enormous concentrations of Peridinium during the bloom period.

It was discovered recently that the reflectance at $670 \mathrm{~nm}$ remains almost constant over a wide range of Chl-a concentrations [5-7]. When phytoplankton density increases, the reflectance near $670 \mathrm{~nm}$ should also increase, due to elevated scattering by phytoplankton cells. Concurrently, the increase in Chl$a$ absorption should lead to a decrease in reflectance. When Chl- $a$ concentration is over $10 \mathrm{mg} / \mathrm{m}^{3}$, the processes of absorption and scattering are almost in equilibrium. Phytoplankton density almost does not affect the reflectance at $670 \mathrm{~nm}$ and it primarily 
depends upon non-pigmented organic and non-organic suspended matter concentrations.

For Chl concentrations of more than $20 \mathrm{mg} / \mathrm{m}^{3}$, minimal attenuation was found at 700-720 nm (Fig. 1), conversely coinciding with maximum in reflectance (Fig. 2b). This maximum near $720 \mathrm{~nm}$ was observed recently in reflectance spectra in different types of water [5-8]. Decrease of Chl absorption and increase of pure water absorption results in minimum of combine absorption curve of algae and water [5, 9-10]. Increase of algal density leads to enhancement of scattering and, as a consequence, to increased reflectance.

For low $\mathrm{Chl}$ concentrations the region near 680 $\mathrm{nm}$ (natural fluorescence signal) is considered the most appropriate feature for gaining information on $\mathrm{Chl}$ concentration [11-12]. For $\mathrm{Chl}$ concentrations of more than $20-30 \mathrm{mg} / \mathrm{m}^{3}$, scattering by phytoplankton cells is the dominant factor in the near infra-red region of the spectrum. It governs spectral behavior of both apparent optical properties: reflectance and vertical attenuation coefficient $[5-7,12]$.

\section{Chlorophyll detection using high spectral resolution data}

The index for Chl estimation should be invariant with respect to all water constituents, but $\mathrm{Chl}$, and not be influenced by survey conditions. For these purposes wavelength where one dominant factor influences spectral feature variation (beside pure water) will be the most useful for determination of constituent concentration. Reflectance spectra acquired in the lake both for low and high $\mathrm{Chl}$ concentrations showed that the red reflectance maximum, near $700 \mathrm{~nm}$, is the only feature expedient for our goal.

Our approach for Chl estimation was to use the reflectance height at the wavelength corresponding to peak maximum above the base line (RLH), spanned between 670 and $750 \mathrm{~nm}$ for low Chl period $\left(\mathrm{RLH}_{670}\right.$ 750) and between 670 and $850 \mathrm{~nm}$ for high Chl period $\left(\mathrm{RLH}_{670-850}\right)$. We calculated the reflectance line height and to compare it to $\mathrm{Chl}$ concentration measured analytically.

For low Chl period (October 1992), the relationship was:

Chl $=1.84+29.4 * \mathrm{RLH}_{670-750}, \mathrm{r}^{2}=0.71$ with an estimation error $<0.6 \mathrm{mg} / \mathrm{m}^{3}$

For high Chl period (March 1993) the relationship was:

Chl $=1.77+40.77 * \mathrm{RLH}_{670-850,} \mathrm{r}^{2}=0.96$, with an error of less than $10.5 \mathrm{mg} / \mathrm{m}^{3}$.

The validation of the model was made by using independent data sets obtained in April and July 1993, yielded an estimation error $<1.35 \mathrm{mg} / \mathrm{m}^{3}$ for low $\mathrm{Chl}$ period and $<6.18 \mathrm{mg} / \mathrm{m}^{3}$ for Peridinium period. .

Other possible approaches for Chl estimation is to use the sum of reflectance above the base line from 670 through $850 \mathrm{~nm}$ as a $\mathrm{Chl}$ indicator. The estimation errors of those algorithms were found of less than 0.48 $\mathrm{mg} / \mathrm{m}^{3}$ for low Chl period and less than $6 \mathrm{mg} / \mathrm{m}^{3}$ for high Chl period [12].

\section{Chlorophyll detection using Landsat Thematic Mapper data}

In order to develop an algorithm for Chl estimation using TM data during low Chl period, the effect of SM on reflectance in the blue region of the spectrum had to be taken into consideration. For this correction, the reflectance in the red region of the spectrum was used. As back scattering due to non-organic SM increases, the reflectance increases across all the visible spectrum. In the red range the part of the reflectance due to $\mathrm{Chl}$ fluorescence was less than $5 \%$ of the total reflectance even for $\mathrm{Chl}=7 \mathrm{mg} / \mathrm{m}^{3}$ (the maximal concentration) and $\mathrm{SM}=1.8 \mathrm{mg} / \mathrm{l}$ (the minimal concentration). The total reflectance in the region 620 to $690 \mathrm{~nm}$ depended almost solely on SM concentration. This conclusion was confirmed by the close relationship between Secchi disk depth and the sum of reflectance in the range from 620 to $690 \mathrm{~nm}$ [2]. Hence, band 3 of TM was used for subtraction from TM1 to correct for the additional radiance caused by scattering of non-organic suspended particles. The relationship between the ratio (TM1-TM3)/TM2 and Chl concentrations gave $r^{2}$ $=0.71$ and allowed the estimation of $\mathrm{Chl}$ with an error $<0.68 \mathrm{mg} / \mathrm{m}^{3}$. The prediction was examined using data extracted from TM image. Calculated from TM image $\mathrm{Chl}$ was compared to the $\mathrm{Chl}$ measured in situ and yielded an error $<0.85 \mathrm{mg} / \mathrm{m}^{3}$. This allowed mapping of $\mathrm{Chl}$ ranging from 3 to $7 \mathrm{mg} / \mathrm{m}^{3}$ with five gradations in concentration.

For Peridinium period the variation of simulated radiance in TM3 $(600-690 \mathrm{~nm})$ was minimal. Its maximal variation was found in TM4 (800-1100 nm). Those findings suggest that $\mathrm{Chl}$ assessment may be feasible using index constructed as a ratio TM4/TM3. This ratio will be maximally sensitive to $\mathrm{Chl}$ concentration and, to a certain degree, invariant with respect to survey condition. The comparison of the simulated radiances (TM4/TM3) with actually measured $\mathrm{Chl}$ concentration gave $\mathrm{r}^{2}>0.92$.

The findings were examined using reflectances extracted from atmospherically corrected TM data. The correlation between TM-derived $\mathrm{Chl}$ and measured $\mathrm{Chl}$ 
concentration, was $\mathrm{r}^{2}=0.79$ with an error $<15.8$ $\mathrm{mg} / \mathrm{m}^{3}$. This allowed mapping of $\mathrm{Chl}$ ranging from 5 to $185 \mathrm{mg} / \mathrm{m}^{3}$ with 10 gradations.

\section{CONCLUSIONS}

The findings of this work support earlier results that the spectral range from green to near infrared is a suitable source for algorithm construction for $\mathrm{Chl}$ assessment in inland and productive coastal waters. We assume that for remote assessment of chlorophyll in inland productive waters, sensor for measurement of radiance with three spectral bands: 670 and $710 \mathrm{~nm}$ (with bandwidth $10 \mathrm{~nm}$ ) and $850 \mathrm{~nm}$ (with bandwidth up to $40 \mathrm{~nm}$ ) will be sufficient.

The stability of the proposed models depend on numerous factors. The main group concerns the inherent optical properties of algal cells, non-organic and detrital particles. Therefore, the parameters to be used in the models pertain to the nature of suspended and dissolved water constituents. Change in taxonomic composition of the phytoplankton, the intrinsic composition of the cells ("package effect"), the particle size distribution of non-living materials and the quantity of dissolved matter will affect the reflected signal.

In this study $\mathrm{Chl}$ concentration was estimated on the basis of a peak of reflectance near $700 \mathrm{~nm}$ that has different nature for low and high $\mathrm{ChI}$ concentrations. Fluorescence is the governing factor creating the peak in the red at low $\mathrm{Ch}$ concentrations, whereas at high $\mathrm{Chl}$ concentrations it is mainly caused by the interaction of $\mathrm{Chl}$ and water absorption. At this stage of our knowledge we could not distinguish between those two mechanisms when $\mathrm{Chl}$ concentrations are neither very low nor conspicuously high. For intermediate concentrations both processes effect the magnitude of this peak. Further investigation is required to understand the role of processes which govern the formation of the peak in the red range of the spectrum. Inherent optical properties of each optically active constituent and factors affecting quantum yield of natural fluorescence, as well, should be studied to create comprehensive algorithms for inland water quality monitoring.

\section{REFERENCES}

[1] H. Gordon and A. Morel, "Remote Assessment of Ocean Color for Interpretation of Satellite Visible Imagery. A Review," Springer-Verlag, New York, 114 p., 1983.
[2] M. Mayo, A. Gitelson, Y. Yacobi, and Z, BenAvraham, "Chlorophyll distribution in Lake Kinneret determined from Landsat Thematic Mapper data," Int. J. Remote Sensing, 15, 1994.

[3] Z. Dubinsky and M. Polna, "Pigment composition during a Peridinium bloom in Lake Kinneret (Israel)," Hydrobiol., 51, pp. 239-243, 1976.

[4] R.A. Neville, and J.F.R. Gower, "Passive remote sensing of phytoplankton via chlorophyll- $a$ fluorescence," J. Geophys. Res., 82, pp. 3487-3493, 1977.

[5] A. Gitelson, A. Nikanorov, G. Sabo, and F. Szilagyi, "Etude de la qualite des eaux de surface par teledetection," IAHS Publications, 157, pp. 111-121, 1986.

[6] A. Gitelson, G. Garbuzov, F. Szilagyi, K.-H. Mittenzwey, A. Karnieli and A. Kaiser, "Quantitative remote sensing methods for real-time monitoring inland water quality," Int. J. Remote Sensing, 14, pp. 1269-1295, 1993.

[7] A. G. Dekker, "Detection of the optical water quality parameters for eutrophic waters by high resolution remote sensing," $\mathrm{Ph} . \mathrm{D}$. Thesis, Free University, Amsterdam, The Netherlands, 212 p., 1993.

[8] G. Quibell, "Estimation chlorophyll concentrations using upwelling radiance from different freshwater algal genera," Int. J. Remote Sensing, 13,pp. 2611-2621, 1992.

[9] A.P. Vasilkov, and O.V. Kopelevich, "The reasons of maximum at about $700 \mathrm{~nm}$ on radiance spectra of the sea," Oceanography, 22, pp. 945-950, 1982.

[10] A. Gitelson, "The peak near $700 \mathrm{~nm}$ on reflectance spectra of algae and water: relationships of its magnitude and position with chlorophyll concentration," Int. J. Remote Sensing, 13, pp. 3367$3373,1992$.

[11] J. Fischer and V. Kronfeld, "Sun-stimulated chlorophyll fluorescence. 1: Influence of oceanic properties," Int. J. Remote Sensing, 11, pp. 21252147, 1990.

[12] A. Gitelson, M. Mayo, Y. Yacobi, A. Parparov, and T. Berman, "The use of high spectral radiometer data for detection of low chlorophyll concentrations in Lake Kinneret," J. Plank. Res., 16, pp. 993-1002, 1994. 